\title{
Accounting Software in Modern Business
}

\author{
Lesia Marushchak ${ }^{1, *}$, Olha Pavlykivska ${ }^{1}$, Galyna Liakhovych $^{2}$, Oksana Vakun $^{2}$, Nataliia Shveda ${ }^{3}$ \\ ${ }^{1}$ Department of Accounting and Audit, Ternopil Ivan Puluj National Technical University, Ternopil, 46001, Ukraine
}

${ }^{2}$ Department of Accounting and Finance, Ivano-Frankivsk Education and Research Institute of Management Ternopil National Economic University, 76000, Ukraine

${ }^{3}$ Department Management and Administration Department, Ternopil Ivan Puluj National Technical University, 46001, Ukraine

\begin{tabular}{l} 
A R T I C L E I N F O \\
\hline Article history: \\
Received: 06 November, 2020 \\
Accepted: 19 January, 2021 \\
Online: 05 February, 2021
\end{tabular}

Keywords:

Accounting software

Leading companies

Accounting system

Business performance

\begin{abstract}
A B S T R A C T
The purpose of the research is an investigation of different accounting software products, their functions, and specific features to make easier choice among variety of similar products and analysis of their pros and cons that can influence on companies' performance. Authors classified accounting software according to its capabilities to serve the different managerial purposes. Because accounting software contains hundreds, some of them even thousands of features, the grouping method gave a possibility to assort similar models that might suit the company's specific requirements - size, cost, customizing, formats, appointments, models, and providers. Observation and comparing of data showed that the cost of accounting programs is critical to making the right choice. As the global accounting software market has a tendency to abrupt change to e-accounting, so that makes it impossible to predict the future behavior of accounting software users. To determine the objectives of this research statistical procedures are conducted. Received results can help potential users of accounting software products to choose the appropriate one based on listed advantages and disadvantages among the best sellers - customization tools, foreign currencies handling, financial and managerial reporting system and analytical capabilities. Lack of prior research studies on the topic and lack of available data have caused significant limitation of the analysis scope. The obtained results gave possibility to identified the main elements in formation the list of features necessary for making right choice of accounting software products. Facts showed managers, who don't consider specific needs and features of accounting software, encounter with problem of discrepancy to company's requirements.

The research is based on theoretical and empirical data. To collect the necessary data for research there was used a quantitative approach. Analytical method helped to analyze and evaluate the ponderable factors which must be considered in selecting process the most appropriate accounting software for companies. The research is dedicated to problems connected with an uncertainty that appears in the accounting software market. This research adds new knowledge to the accounting field as there was disproving theoretical and practical knowledge about accounting software.
\end{abstract}

\section{Introduction}

Accounting software has become an integral part of all types of business. Nowadays accounting and financial management became the scientific tools in running the business where software programs help to manage finance more effectively. Companies also spread their activities on international markets to get their

\footnotetext{
*Corresponding Author: Lesia Marushchak, lesyamar@ukr.net
}

www.astesj.com

https://dx.doi.org/10.25046/aj060195 shares and as a result, there is an increased demand for new and more sophisticated accounting software packages capable for handling international accounting issues [1]. There are more than 150 well-identified software products around the world and most of them are targeted on large business. But the main stress must be made especially on small business as companies this size are most unprotected and cannot finance much in accounting programs. There are a number of vendors which serve this share 
of market [2], but there is a very short list of scientific researchers conducted on this theme which would help business owners make the right and cost suitable choice.

As accounting systems are connected with other management platforms such as inventory management, warehouse management, order management, customer relationship management, enterprise resource planning, sales and production planning, enterprise quality management, supply chain and distribution systems, accounting software must be more than the simple programs for record and storage accounting information. Except this point, when it comes to select the right accounting product, the choices can be contradictory how to choose necessary speed, accuracy and reliability. The relationship between accounting software and company performance might be distinguished only in case when the accounting software program is suitable for some special company features. It also should be stressed that many specialists are involved in the accounting process. Many conducted researches showed that accounting information system adoption really influenced effectively on companies' performance, profitability and operations efficiency in some countries: Malaysia, Finland, Spain, Iran and Pakistan [3]-[6]. But there is also limitation in similar researches in the EU countries.

So, an accounting software program together with specialists and methods used to gather financial information about business events create the accounting information system. Accounting software without other components of AIS is the only device for recording and storage of information. Owners often buy simple accounting software with limited functional specification and do not get all possible results when it connects with other managerial systems. Choosing among cloud accounting and traditional accounting software is the main dilemma and problematic challenge for a lot of small and medium sized businesses and the important issue of current research.

Problems related to the right choice of accounting software programs could be solved only in complex: with selection of appropriate interconnected technical components - input and output devices, information storage and processors; and after deep examination of all accounting software pros and cons.

Current research has shown that it is important for companies to make special investigation to find what type of accounting software is necessary and suitable for satisfaction of accounting and managerial needs. There was made authors' contribution to develop knowledge in the theoretical and practical acquisition of accounting sphere. There have no researches been conducted which would show statistical analyses of companies produce accounting software according to different types, comparison of price policies and only few researches were conducted to evaluate the impacts of using accounting software on the companies' performance (only in separate countries).

\section{Literature Review}

Professional technologies have changed the way professionals conduct accounting. For past several decades accounting software has been used only to conduct monetary transactions between companies and with individuals but with time it became more complex. Nowadays accounting software is an effective tool in managing business processes. There are thousands of firms producing different kinds of accounting software. Managers collide with problems in choosing the most suitable accounting software to fit all companies' requirements.

Many scientists tried to investigate the influence of accounting information system (AIS) on the performance of all types of business. But most of them are connected to separate countries. Research [7] showed the influence of accounting information systems (AIS) on the performance of small and medium enterprises (SMEs) in Iraq and proved that AIS is one of the most important indicators for SMEs sustainability. Another author [8] investigated the impact of accounting software on the business performance of Malaysian firms. The research was based on participants' attitudes towards the importance of AIS. Results were positive and the author affirmed that accounting software has the significant importance and a great value to businesses, organizations and the economy. Some scientists [9] indicated that accounting software plays a critical role in the creation of quality accounting information and in storage necessary information to the decision-makers. In scientific paper was [10] investigated the impact of accounting information systems on organizational performance in the context of Saudi's SMEs and there was defined that it is a tool that helps to improve control of company's managers about business performance. It also can reduce the cost of accounting spending. Accounting software has a direct influence on the quality of financial statements submitted to the different state departments. Conducted investigation [11] showed the sufficient impact of accounting IS on the quality of financial statements, time of their preparation in Jordan and showed the positive result in case of its usage. Several scientists conducted research connected with defining the impact of AIS on performance measures in a case of Spanish SMEs, [12] and they found that it has a positive influence on outcome indicators and productivity. Other scientists went ahead and proved that with rapid technological development the transactions of a business are becoming more complex than it was ever that course more demand for control. Good accounting software can put a business in efficient control.

But in the literature, there are almost no scientific approaches to the classification of features and specifications of accounting software which can meet separate requirements of companies according to their sizes. Only a few accounting software types were analyzed according to their advantages and disadvantages.

\section{Results: Theoretical Background}

Accounting tasks are spreading each year; it is much than a booking, so many specialists have been thought about simplification of accountants' work and making storage of information more reliable. A computerized accounting system could be defined as an effective means of keeping accounting records in the electronic version. Accounting software is a special class of computer programs that helps to manage a business. The most suitable definition of 'accounting software' was given by Barron's Accounting Dictionary: 'Accounting software are programs used to maintain books of account on computers. The software can be used to record transactions, maintain account balances, and prepare financial statements and reports'[13]. Many accounting software programs are designed to create simple 
money transactions (bookkeeping) between companies and others to record entire financial comings and goings for simplifying analysis procedures and decisions making processes. It depends on their scopes and functions.

History of accounting software. Most accountants affirm that accounting software is an invaluable tool for modern business but at first it was only appointed to simple operations storage. And the essential meaning of accounting software was recording financial data and later its function was extended to turning it into useful financial information [14]Error! Reference source not found.. With time professionals titled the accounting software as a 'magic wand', since before the computerizing of accounting transactions many tasks were conducted by hands and companies kept large transaction journals. The change happened only in the $20^{\text {th }}$ century when computers transformed accounting significantly. The first computer for accounting purposes was sold in 1955 [15]. Later, Peachtree Software introduced the first accounting software in 1978 - a package for the early personal compute [16]. The Internet era has caused a significant increase in demand for accounting software. A list of companies and competitiveness among them has been increasing each year. Such innovation gives a real picture of the company's performance or as it is modishly to talk 'fair view' and 'health status of company'.

Functions, features and requirements to users. But even though the automated program makes mach manual accounting and bookkeeping easier processes, all software should meet the necessary requirements for legal and ethical characteristics of each country. The general functions of accounting software in IAS are analyzed in Figure 1.
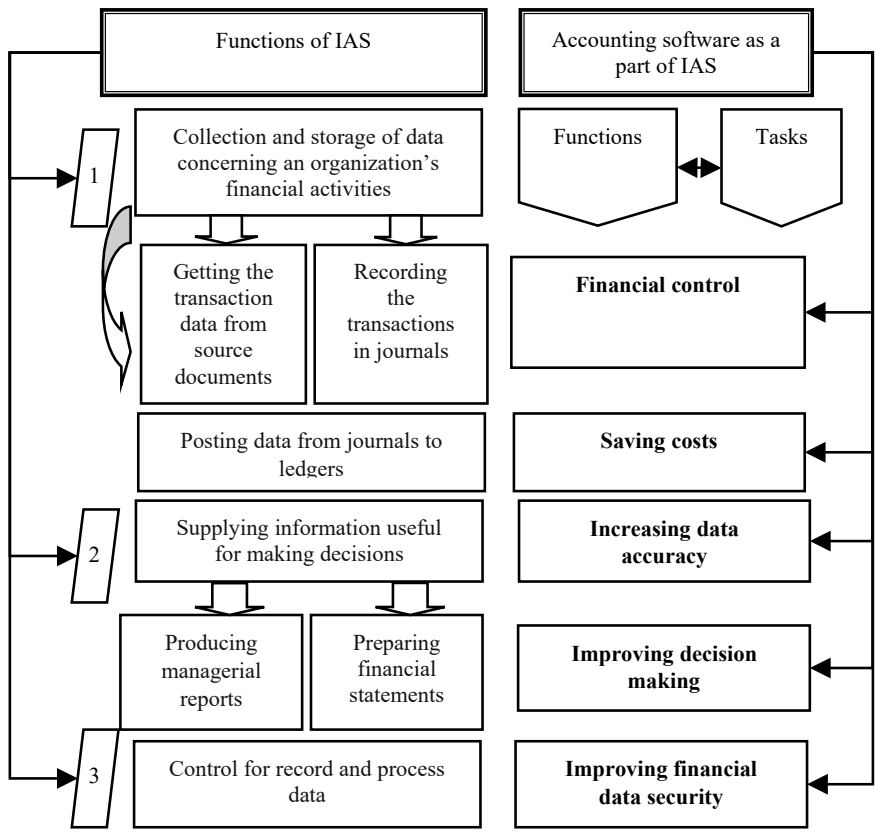

Figure 1: Managerial functions and tasks of accounting software in complex with IAS [17]; [14]

Accounting software has standard functions in the accounting field reflected in Figure 2.

The speed and accuracy of operations are the main characters of accounting software. Scientists also emphasize two other features of such computer programs; one of them is the managing of resources more efficiently in accounting departments and other reducing of costly bookkeeping mistakes [18]. Calculation of math figures and sums in the accounting process became far easier with new computer technology.

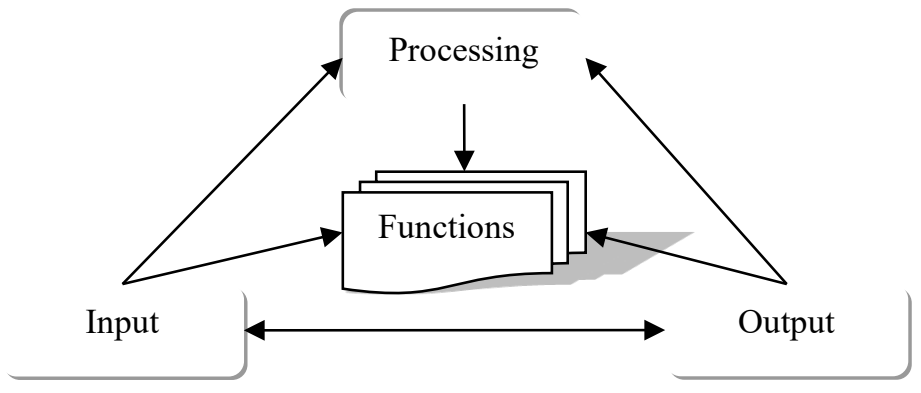

Figure 2: Productive (basic) functions of accounting software

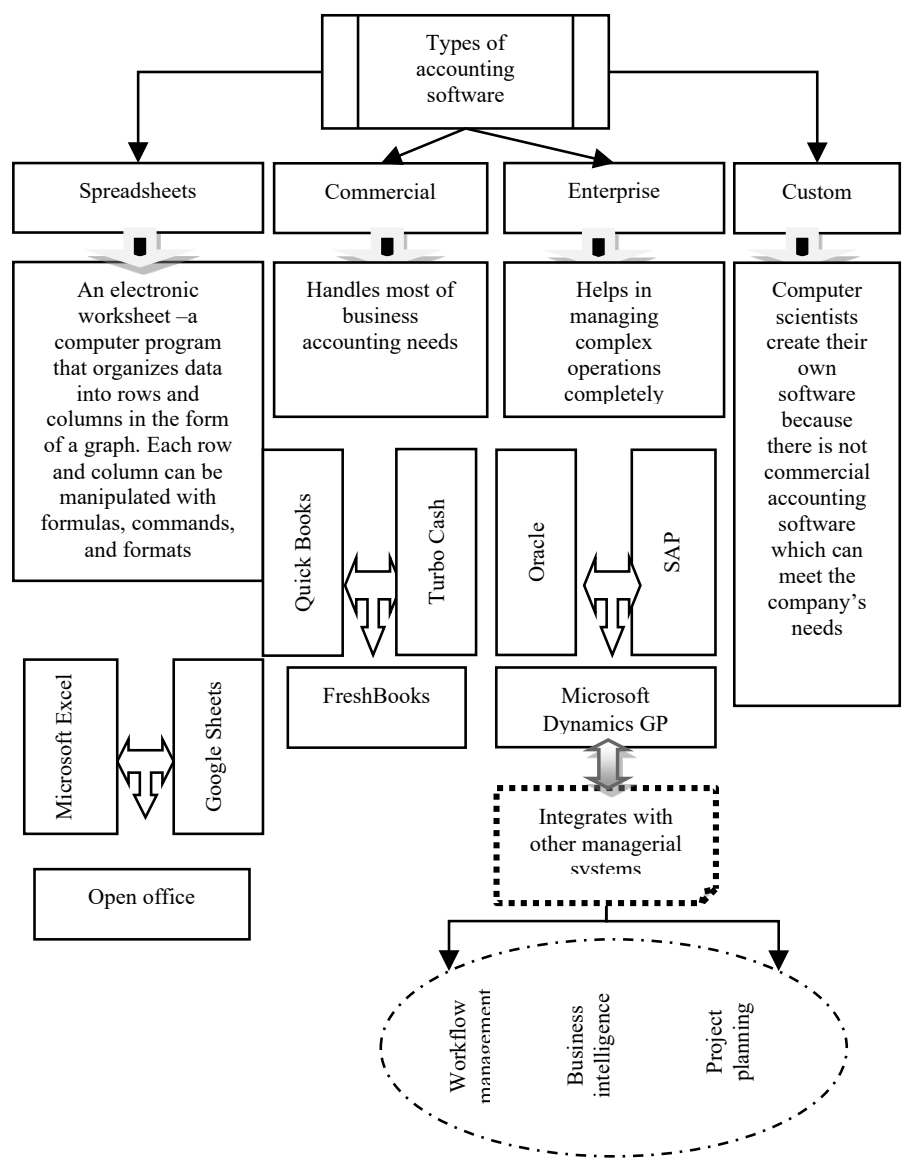

Figure 3: Types of accounting software [20]

But there was not proved how much time was reduced in an accounting cycle after computer programs appeared. Overall work from all departments is faster because a computer can keep and calculate thousands of indicators simultaneously. Most of managers and business owners separate another controversial dilemma - the requirement of qualified accountants on each stage of the accounting process. In past years accountants had to obtain necessary education, knowledge and experience in the accounting sphere and then they could work with accounting procedures for a long period, only changes in Government Standards on the state level required of Certification training or additional educational programs (courses). Accounting computer programs work faster 
but only after clearly defined tasks. Computerized accounting procedures require accountants who can use specific software and therefore special computer skill. Only few accountants have possibilities to obtain the necessary qualification and experience themselves. Others need special education or training. But it is additional expense for many business owners. This problem is also connected with the high cost of training courses. But, the future benefit is higher than temporary expenses. Moreover, AIS can easily integrate with other management systems of enterprises.

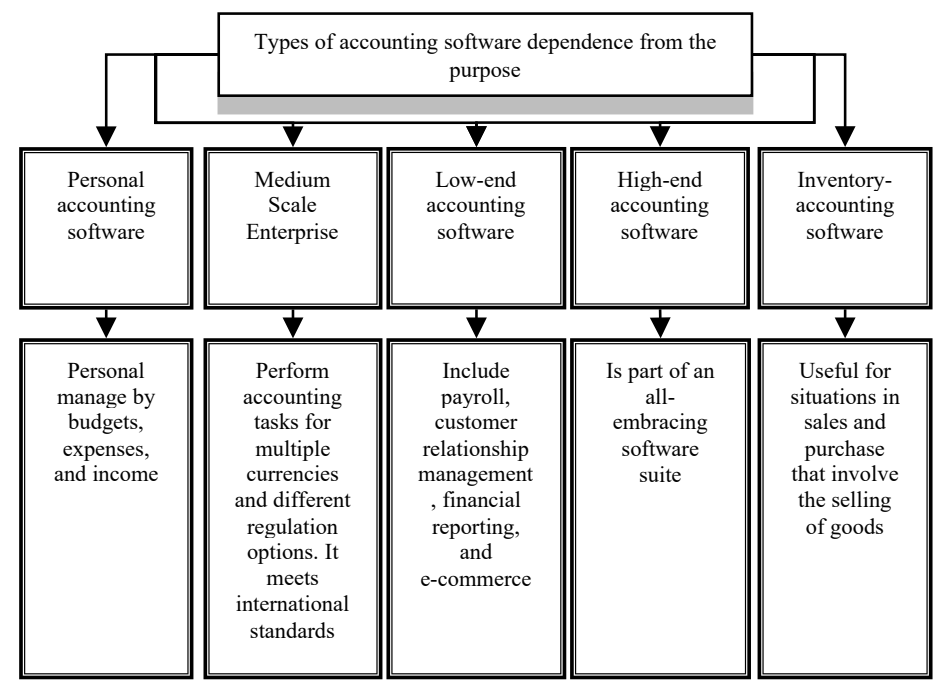

Figure 4: Types of accounting software serving the different purposes [24]
Accounting software has a row of advantages and disadvantages. But most practitioners do not take into account them; this is evidenced by fact that almost all organizations and companies have used computer programs for accounting purposes in everyday business [19]. Scientists predict that computerization of accounting work will continue in the future as managers have value benefit from it - a stable source of information expressed in three forms - a document query, report and results of calculation (mostly expenses and income).

The effectiveness level of accounting software units depends on many factors such as types, appointments and their functions (Figure 3).

It is also necessary to stress on other classification of accounting software [22], where the author excreted three types of accounting software - database, installed and cloud. Large companies and corporations need to secure own data so owners install database software that has a higher level of security, fulfills more complex tasks, integrates with large network and complicated accounting functions (ex. Oracle). Installed accounting software is useful for businesses where internet connection is limited or absent. Meanwhile, cloud accounting is becoming more popular among startups and small-sized companies (ex. Freshbooks, Quickbooks, Xero and Sage 50 Premium Accounting in different versions). Currently, 6\% of SMEs use a 'cloud-based' accounting system worldwide [23]. There is also another classification of software which fits accounting purposes [24], and it is reflected in Figure 4.

Table 1: Advantages and disadvantages of accounting software

\begin{tabular}{|c|c|c|c|c|c|}
\hline \multicolumn{6}{|c|}{ Advantages and disadvantage of separate accounting software } \\
\hline \multicolumn{2}{|c|}{ Cloud accounting software } & \multicolumn{2}{|c|}{$\begin{array}{l}\text { Commercial accounting software } \\
\text { (Peachtree) }\end{array}$} & \multicolumn{2}{|c|}{ Enterprise accounting software } \\
\hline Pros & Cons & Pros & Cons & Pros & Cons \\
\hline $\begin{array}{l}\text { Lower operational costs } \\
\text { (investment, } \\
\text { maintenance is absent), } \\
\text { this type of accounting } \\
\text { software is cheaper } \\
\text { then purchasing } \\
\text { software }\end{array}$ & $\begin{array}{l}\text { Stable demand in } \\
\text { access to the } \\
\text { internet connection }\end{array}$ & $\begin{array}{l}\text { Offer a set of the } \\
\text { most widespread } \\
\text { features to } \\
\text { perform } \\
\text { accounting tasks }\end{array}$ & Comparable high cost & $\begin{array}{l}\text { Easy to install } \\
\text { on a system } \\
\text { and deploy to } \\
\text { end-users } \\
\text { quickly }\end{array}$ & Comparable high cost \\
\hline Higher reliability & $\begin{array}{l}\text { There is the risk of } \\
\text { data confidentiality } \\
\text { (hacking - there is } \\
\text { no guarantee that } \\
\text { data is } 100 \% \text { safe) }\end{array}$ & $\begin{array}{l}\text { Affordability for } \\
\text { companies' } \\
\text { owners - the } \\
\text { average cost }\end{array}$ & $\begin{array}{l}\text { There is a small but } \\
\text { real possibility to } \\
\text { lose information if } \\
\text { the system is attacked } \\
\text { by computer viruses } \\
\text { in case it is not } \\
\text { enough protected }\end{array}$ & $\begin{array}{l}\text { Easy to } \\
\text { customize }\end{array}$ & $\begin{array}{l}\text { There is a small but } \\
\text { real possibility to lose } \\
\text { information if the } \\
\text { system is attacked by } \\
\text { computer viruses in } \\
\text { case it is not enough } \\
\text { protected }\end{array}$ \\
\hline $\begin{array}{c}\text { Higher accuracy (fewer } \\
\text { mistakes). Much easier } \\
\text { tools then other types } \\
\text { propose }\end{array}$ & Technical problems & $\begin{array}{l}\text { There is no } \\
\text { demand in well- } \\
\text { experienced skills }\end{array}$ & $\begin{array}{l}\text { Increasing of } \\
\text { productivity }\end{array}$ & $\begin{array}{l}\text { Meet almost } \\
\text { all user } \\
\text { requirements }\end{array}$ & $\begin{array}{l}\text { The necessity of high } \\
\text { qualified personals }\end{array}$ \\
\hline $\begin{array}{l}\text { Pay only for } \\
\text { subscription }\end{array}$ & $\begin{array}{l}\text { Vendor lack-in/ } \\
\text { lack-of control }\end{array}$ & $\begin{array}{l}\text { High level of } \\
\text { security }\end{array}$ & $\begin{array}{l}\text { Flexibility and } \\
\text { timeliness }\end{array}$ & $\begin{array}{l}\text { Increasing } \\
\text { productivity }\end{array}$ & On-going support \\
\hline $\begin{array}{c}24 / 7 \text { access and } \\
\text { possibilities to recover } \\
\text { data (restore) }\end{array}$ & $\begin{array}{c}\text { In some cases limits } \\
\text { to the data that can } \\
\text { be freely store }\end{array}$ & Low risk & $\begin{array}{l}\text { The necessity of high } \\
\text { qualified personals }\end{array}$ & $\begin{array}{l}\text { Management } \\
\text { information }\end{array}$ & $\begin{array}{c}\text { Mistakes in data entry } \\
\text { can throw off a whole } \\
\text { set of data }\end{array}$ \\
\hline Collaboration & $\begin{array}{c}\text { A lack of } \\
\text { specialized tools }\end{array}$ & $\begin{array}{l}\text { Flexibility and } \\
\text { timeliness }\end{array}$ & $\begin{array}{c}\text { Mistakes in data entry } \\
\text { can throw off a whole } \\
\text { set of data }\end{array}$ & $\begin{array}{l}\text { Flexibility and } \\
\text { timeliness }\end{array}$ & Can be inflexible \\
\hline
\end{tabular}


Table 2: Cost comparison of 12 top accounting software programs and description of their capabilities [27]Error! Reference source not found.; [28]; [29]; [30]; [31]; [32]; [33]

\begin{tabular}{|c|c|c|c|c|c|}
\hline № & $\begin{array}{l}\text { Accounting } \\
\text { software }\end{array}$ & Form & Manufacturer & $\begin{array}{l}\text { Cost, \$ per } \\
\text { month } / y\end{array}$ & Appointment \\
\hline \multicolumn{6}{|c|}{ For start-ups, small and medium-sized businesses } \\
\hline \multirow[t]{2}{*}{1} & \multirow[t]{2}{*}{ QuickBooks } & Online & \multirow{2}{*}{$\begin{array}{c}\text { Intuit } \\
\text { United States }\end{array}$} & $20-150$ & \multirow{2}{*}{$\begin{array}{l}\text { Easy for working accounting software with features that can satisfy } \\
\text { complex accounting needs: reconciliation, taxes, reporting and } \\
\text { inventory management. 4,5 million customers globally use } \\
\text { QuickBooks }\end{array}$} \\
\hline & & Desktop & & 299,95 & \\
\hline 2 & FreshBooks & & $\begin{array}{l}\text { Designed by Mike } \\
\text { Mc Derment in } \\
\text { Toronto, Ontario }\end{array}$ & $6-20$ & $\begin{array}{l}\text { FreshBooks is a cloud-based accounting designed software. It is ideal } \\
\text { for freelancers (accountants) and small businesses that look to fast } \\
\text { track their sales cycle and keep their processes in line with standards } \\
\text { and regulations. Over } 12 \text { million users in } 120 \text { countries }\end{array}$ \\
\hline \multirow[t]{2}{*}{3} & \multirow{2}{*}{$\begin{array}{l}\text { Accounting by } \\
\text { Wave }\end{array}$} & Online & \multirow{2}{*}{$\begin{array}{c}\text { Wave } \\
\text { (Wave Apps) }\end{array}$} & \multirow{2}{*}{$\begin{array}{l}\text { Free (only } \\
\text { several } \\
\text { payroll } \\
\text { services) }\end{array}$} & \multirow{2}{*}{$\begin{array}{l}\text { It is a very suitable and free accounting software for many owners of } \\
\text { small companies. It is a powerful bookkeeping. Easily integrates with } \\
\text { other management systems of companies }\end{array}$} \\
\hline & & $\begin{array}{l}\text { Mobile } \\
\text { version }\end{array}$ & & & \\
\hline 4 & FreeAgent & $\begin{array}{l}\text { Cloud- } \\
\text { based }\end{array}$ & FreeAgent Central & Free & $\begin{array}{l}\text { It is the accounting software for small business in the UK. There are } \\
\text { over } 80000 \text { small business users. }\end{array}$ \\
\hline \multirow[t]{2}{*}{5} & \multirow[t]{2}{*}{ Manager } & Online & \multirow[t]{2}{*}{ NGSoftware } & \multirow[t]{2}{*}{ Free } & \multirow[t]{2}{*}{ For a small business, all industries, 70 languages } \\
\hline & & Desktop & & & \\
\hline \multicolumn{6}{|c|}{ For mid-sized and large businesses } \\
\hline 6 & $\begin{array}{l}\text { QuickBooks } \\
\text { Enterprise }\end{array}$ & - & $\begin{array}{c}\text { Intuit } \\
\text { United States }\end{array}$ & $1419-3442$ & $\begin{array}{l}\text { The end-to-end accounting software designed for growing business. } \\
\text { Usage of the program helps to manage inventory, run payrolls, track } \\
\text { sales and report. This type of software manages accounting } \\
\text { transactions from start to finish. } 135000 \text { companies chose QuickBooks } \\
\text { Enterprise. There is another version QuickBooks Desktop Enterprise } \\
\text { 20.0. } \\
\text { Users: manufacturers, wholesalers, retailers and nonprofit (for } \\
\text { different industries) }\end{array}$ \\
\hline 7 & Xero & Online & $\begin{array}{c}\text { Xero } \\
\text { (New Zealand) }\end{array}$ & $20-40$ & $\begin{array}{l}\text { It is the smart online accounting for small business. Experts consider } \\
\text { this type of accounting software one of the best for growing companies. } \\
\text { It is also suited for mid and large businesses. }\end{array}$ \\
\hline 8 & Finsync & $\begin{array}{l}\text { Cloud- } \\
\text { based }\end{array}$ & Finsync & From 40 & $\begin{array}{l}\text { It is a powerful accounting software (all-in-one) with different options. } \\
\text { All types of business can use it. }\end{array}$ \\
\hline 9 & NetSuite & $\begin{array}{l}\text { Cloud- } \\
\text { based }\end{array}$ & Oracle & - & $\begin{array}{l}\text { It is suitable accounting software for companies that have grown out } \\
\text { of their accounting software and are ready for full ERP }{ }^{1} \text { software }\end{array}$ \\
\hline 10 & Zoho Books & Online & Zoho & $9-29$ & $\begin{array}{l}\text { The main features of accounting software are: end-to-end accounting, } \\
\text { easy collaboration and integrated platform }\end{array}$ \\
\hline 11 & $\begin{array}{l}\text { FinancialForce } \\
\text { accounting }\end{array}$ & $\begin{array}{l}\text { Cloud- } \\
\text { based }\end{array}$ & FinancialForce & From 175 & $\begin{array}{l}\text { This accounting software is designed for the companies with } \\
\text { employees } 100+\text {. It allows managing company's accounting and it } \\
\text { works with a large amount of data. It also boasts powerful features. } \\
\text { Experts prove that accounting software can satisfy complex enterprise } \\
\text { requirements. The main characters of the product are multicurrency } \\
\text { and global tax }\end{array}$ \\
\hline \multirow[t]{2}{*}{12} & $\begin{array}{l}\text { MYBOS } \\
\text { Accounting \& } \\
\text { Billing }\end{array}$ & Desktop & \multirow[t]{2}{*}{$\begin{array}{l}\text { SBSCC } \\
\text { Sri Lanka }\end{array}$} & 249 & \multirow{2}{*}{$\begin{array}{l}\text { Full integrated multi-user accounting software. In general, this } \\
\text { accounting software is for medium-sized business. It is also accounting } \\
\text { management that helps companies' owners to control sales and } \\
\text { purchases, inventory, and journal entries. For companies, it is possible } \\
\text { to obtain a hybrid cloud system }\end{array}$} \\
\hline & $\begin{array}{l}\text { MYBOS } \\
\text { Accounting on } \\
\text { Cloud }\end{array}$ & Online & & 199 & \\
\hline
\end{tabular}

Some special industries order to design separate accounting software which belongs to Commercial off-the-shelf software. These are positive determinates of selecting accounting software. But other features might influence the appropriate choice of accounting software. Owners must choose among free, paid, or online accounting software. Most of the producers give a trial period for testing their products. In [25], the author stressed that selecting the most appropriate accounting software package has become one of the most critical decisions for most organizations in the fast-changing business world. A choice depends on the advantages and disadvantages of accounting software packages.

Vendors of accounting software try to advertise the main positive aspects of their products and it is very hard to exaggerate meaning of benefit from the accounting software. But many owners have a predisposition to make choice among types of software which give not only gain inside of companies but competitive advantages in the marketplace. In the question of 
choice among accounting software advantages must overweight completely disadvantages (Table 1).

The list of some of the best accounting software for three groups of business according to size is reflected in Figure 5.

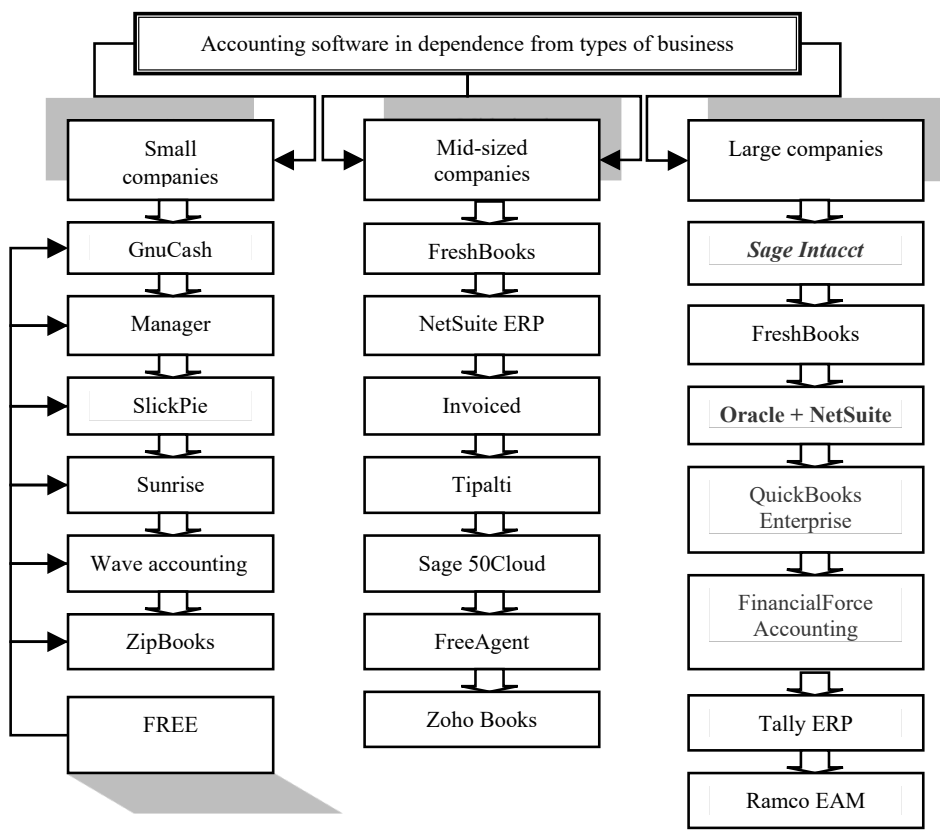

Figure 5: Different accounting software for three types of business

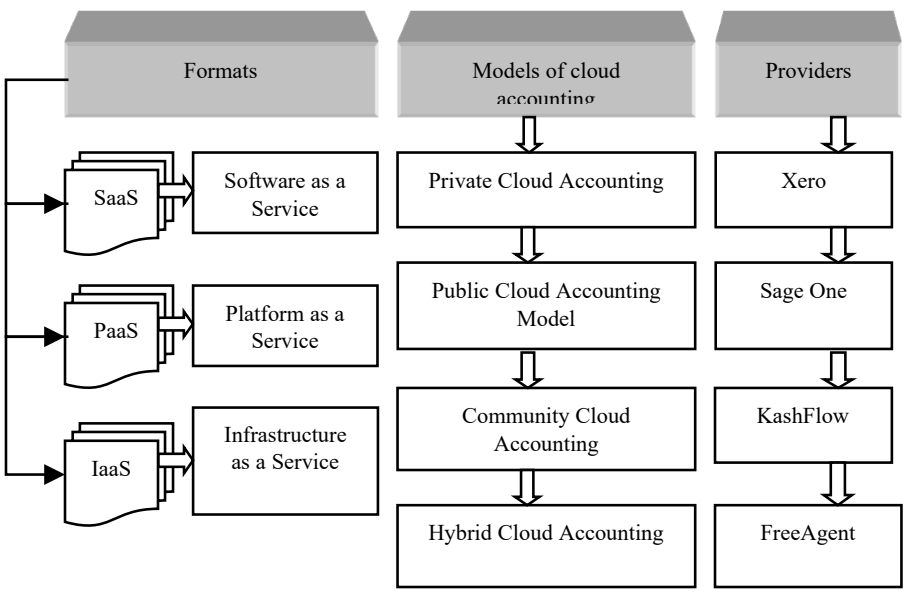

Figure 6: Brief characteristic of cloud accounting system [26]

There are other suitable accounting software programs for different types of business. More and more consumers need special software that contains features of effective management. Nowadays, true and fast information for external and internal users is only one of the main reasons for the purchase of accounting software. Cloud accounting software: This term appeared in far 2011. It gives the possibility to perform all accounting functions through internet-based devices. The main features of cloud accounting are shown in Figure 6.

Cloud accounting is a more flexible system with one strong requirement - connection to the internet. It is appointed to work with traditional accounting functions, updates financial information automatically and provides complex financial reports.

\section{Practical aspects of accounting software choice}

Cost of accounting software: The world market is full of different accounting programs with a variety of capabilities. Prices for accounting programs vary from several dollars to thousand. It depends on many factors and the number of users supported it. The cost of accounting software includes installation, implementation, training programs for users, customizing the software, and operational costs. Nowadays, many producers offer accounting programs on a cloud base and the number of venders who sell licenses has been decreasing each year. It is better for producers to get charge a monthly subscription fee from users. For small businesses and start-ups, the most appropriate accounting software is QuichBooks, Wave, Manager and FreshBooks, but some of their manufactures offer packages for growing business and thriving firms with competitive items. For large companies, there are several worldwide famous accounting software producers such as Intuit (USA), Xero (New Zealand) and Oracle (USA), (Table. 2).

The price is the second indicator which influences on the right choice. For small companies the price is affordable, it varies from $\$ 5$ to $\$ 500$ (Figure 7). But companies with multinational transactions and a large amount of staff need accounting software with additional opportunities and integration capabilities. The scientist [34] advised to choose optional enterprise-class accounting software that can meet the company's specific needs but the price is higher accordingly.

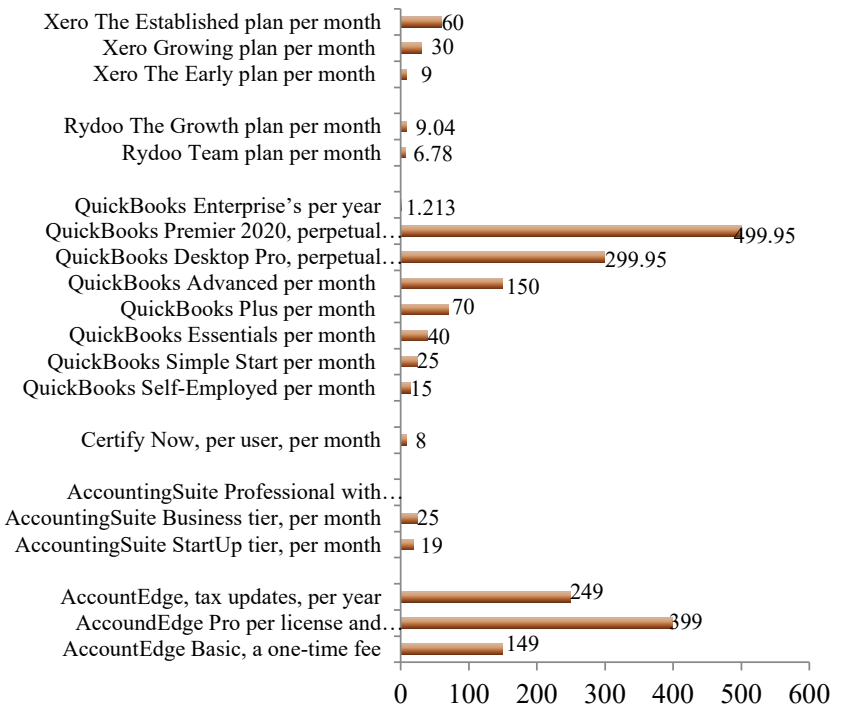

Figure 7: Compression of the prices for different accounting software products [35]

Many manufactures of accounting software offer additional payment options for some special requirements. Byers also desire to combine accounting software with human resources management (HRM) and $\mathrm{POS}^{2}$ (software) systems; integration with the last one is limited in many accounting products. The right

${ }^{2} \mathrm{POS}$ - point of sale. 
accounting system must be adopted not only for information gathering but for synchronizing transactions, serving with oversight into the company's position, and proposing accounting solutions. The other point which must be accounted by users is a pricing policy for accounting software. Venders offer two popular pricing models: subscription-based on a cloud platform or 'payas-you-go' model $^{3}$ and perpetual licensing. Subscription price must be made monthly/year and it guarantees necessary support and maintenance. Some venders give buyers a choice to use all components, special modular components or features they need and pay for them. Many designers of accounting software include additional services and support in the base price of core products but others offer additional features, or modules for an extra payment. Before making the eventual choice for any type of accounting software it is very important to learn whether venders have professionals who are specializing in installation, supporting, and integrated with other company's systems processes or they involve the third party. Third-party consultants sometimes have divergences. It is worldwide accepted to provide the basic training services for free but there are some exceptions.

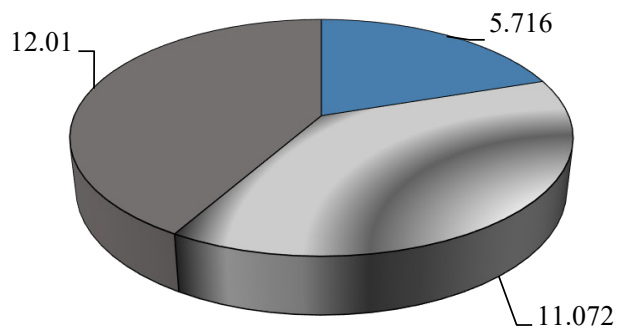

$\square 2017$

๑2018

$\square 2019$

Figure 8: Global accounting software market in 2017-2019, Bn, USD dollars [36]-[38]

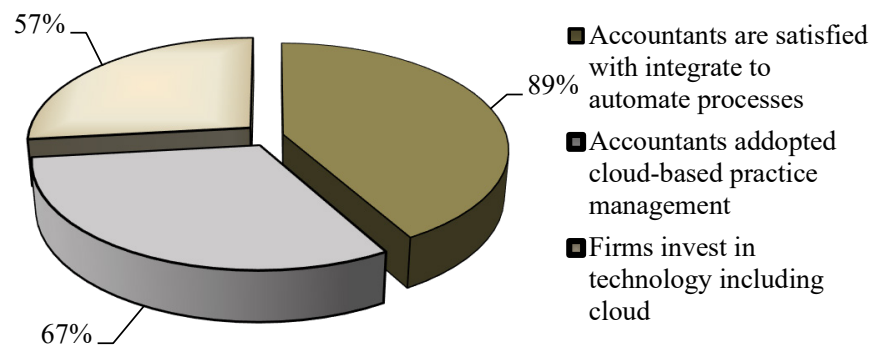

Figure 9: Perception of cloud technologies by accountants, 2017 [39]

The global market of accounting software: The market size of accounting software has been increasing each year and scientists predict the continuation of this tendency for the next few years (Figure 8). Most of the rising is observing in the cloud-based sector. Now, cloud accounting replaced the old desktop versions. Many business owners invest in the cloud accounting system that gives the future long-term benefit in a case when they plan to expand their activity. It is always useful to exploit such type of software when a lot of employees work on the same data. Large companies which are represented by foreign branches perceive cloud-based accounting software more flexible. Most of the users are worried by one main question - is it enough safe? It's protected by the individual password. Accounting software providers also create backup servers in different locations for reinsurance if one server would go down, users can access to necessary data. Excess to cloud accounting software is more protected than the traditional one. The team of 'Finances Online' investigated that more than $50 \%$ of owners and accountants are satisfied by the cloud accounting platform (Figure 9).

Other useful statistical data shows that companies have increased their profits after adopted online accounting (Figure 10).

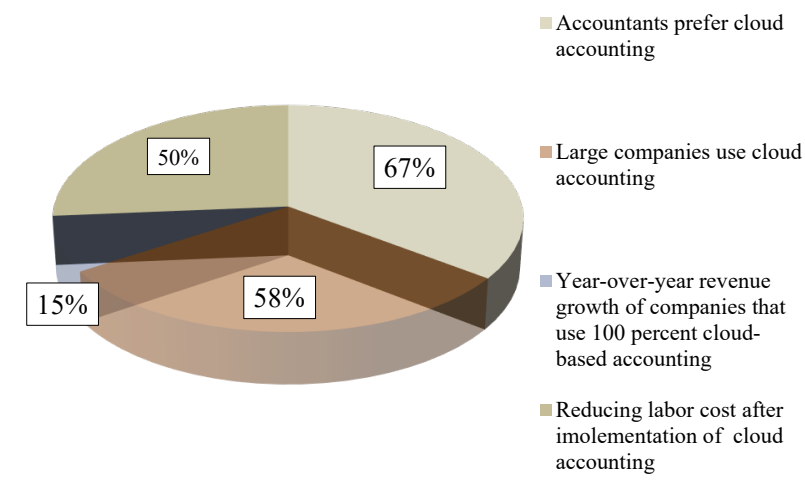

Figure 10: Cloud accounting statistics in 2018 [40]

Any type of accounting software is a great solution for each business as its advantage's overweight disadvantages. There is a huge variety of accounting software, producers, and venders. Many specialists try to model the best one or make the most suitable for all businesses. But the best accounting product for one company might not be the best for another even with similar features. The main character which must fit all customers is trust in it.

\section{Accounting Software Influence on Companies Performance}

Accounting software provides companies' owners and managers with quick and easy reports for decision making [41]. Accounting system can effect on all spheres of activity [42] and has positive influence on companies' performance. Appropriate accounting software gives some benefits, the most important among them are affordability, time savings, higher accuracy and one place for all financial tasks; they are all available to each form of business.

\section{Generalization of Results}

Accounting software in modern business plays very important role and it is a great progress made in the accounting sphere. The main goal of accounting software is tracking financial transactions and generating various financial reports. It is a part of whole accounting systems which might include different types of software from simple transaction-entry programs to advanced accounting systems integrated with other management

\footnotetext{
${ }^{3}$ Pay-as-you-go system is one in which you pay for a service before you use it and you cannot use more than you have paid for. Cambridge Dictionary. 
programs of the company. Accounting software makes accountants work easier and gives information about the 'true health' of business, companies' owners agree to pay a substantial sum for complicated and advanced accounting technologies. Companies with foreign branches have always troublesome issues with coordination among them (mainly a time of reports' delivery that could cause a delay in decision making process) but after cloud technologies appeared, most problems have solved. Cloud accounting or e-accounting is rather a new type of service than IT. The main advantage of cloud accounting software is no time and place limitation as well as putting the whole accounting system to the cloud-based platform.

Analyzed scientific researches proved the positive interrelationship between accounting software and business performance. But in this relationship, many factors have an indirect influence. There are several benefits for companies' owners who use such software: the establishment of financial control, saving costs, increasing data accuracy, and improving data security. With a good accounting system, accountants and business owners can make financial forecasting and improve the decision-making process.

Nowadays, the global accounting market is represented by a lot of producers who offer from traditional old desktop accounting software to the modern cloud-based platforms on license subscription conditions. The tendency of the global market has a positive and stable increasing character. Research showed that more than $60 \%$ of accounting specialists are satisfied with their current accounting programs and most of them are ready to invest in accounting technologies for getting future benefits. Most specialists affirm that cloud-based accounting software together with other intelligent online programs is the future of accounting.

\section{Conclusion}

Research showed a significant increasing of accounting software popularity and that fact has caused sufficient diversification in computer accounting programs. And it's becoming difficult to decide which one to choose. There was grouping of accounting software programs of the most famous world producers using affordable and easy-to-use approaches, listed their advantages and disadvantages, analyzed price policy parameters. There were indicated items to keep in mind when selecting accounting software for companies: special features (accounts receivable and accounts payable tools, track inventory, time tracking, project management, payroll or advanced reporting capabilities), usability (desktop software, cloud software or mobile version and number of users) and costs (inexpensive, average price or expensive with extra features). Also research reports about some risks which connect with storage accounting date and information. As recommendation there are some offers for each type of accounting software program - to give detail explanation on its security level, use multi-business support, find providers with additional services and possible training programs.

\section{Conflict of Interest}

The authors declare no conflict of interest.

\section{References}

[1] M.I. Ajay Adhikari, "Firm characteristics and selection of international accounting software," Journal of International Accounting and Taxation, 13(1), 59-63, 2004.

[2] M. Burns, "Customer survey roundup," CA Magazine, Retrieved June 15, 2013.

[3] B. Gullkvist, "Towards Paperless Accounting and Auditing," E-Business Research Centre, 87-98, 2002.

[4] H. Sajady, M. Dastgir, H. Hashem Nejad, "Evaluation of the effectiveness of accounting information systems," International Journal of Information Science and Management, 6(2), 49-59, 2008.

[5] K. Saira, M.A. Zariyawati, M.N. Annuar, "Information System and Firms," International Business Research, 3(4), P28, 2010.

[6] R. Kouser, A. Awan, Gul-e-Rana, F.A. Shahzad, "Firm size, leverage and profitability: Overriding impact of Accounting Information System," Business \& Management Review, 1(10), 58-64, 2011.

[7] E. Harash, "Accounting performance of SMEs and effect of of accounting information system: A conceptual model," Global Journal of Management and Business Research (D), 17(3), 21-26, 2017.

[8] I.N. Ch.Yvonne, "The impact of accounting software on business performance," International Journal of Information System and Engineering, 6 (1)(November 2017), 2018, doi:10.24924/ijise/2018.04/v6.iss1/01.26.

[9] D.M.J. Wickramsainghe, R. Pemarathna, N. Cooray, T. Dissanayake, "Impact of accounting software for Business Performance," Imperial Journal of Interdisciplinary Research (IJIR, 3(5), 1-6, 2017.

[10] Trabulsi, "The Impact of Accounting Information Systems on Organizational Performance : The Context of Saudi 's SMEs," International Review of Management and Marketing, 8(2), 69-73, 2018.

[11] A.A.J. Abdallah, "The impact of using accounting information systems on the quality of financial statements submitted to the income and sales tax department in Jordan," European Scientific Journal, 1(December), 41-48, 2013.

[12] E.U. Grande, R.P. Estébanez, C.M. Colomina, "The impact of accounting information systems (AIS) on performance measures: Empirical evidence in spanish SMEs," International Journal of Digital Accounting Research, 11(June 2010), 25-43, 2011, doi:10.4192/1577-8517-v11_2.

[13] J.K.S. J.G. Siegel, Dictionary of Accounting Terms, Third Edit, 2000.

[14] Accounting Information System, Aziroff, 2019.

[15] B. Scott, The Accounting Journal: 60 years of accounting software, MYOB, 2015.

[16] F. Sherman, The History of Computerized Accounting, Career Trend, 2019.

[17] Kanya, The Importance of Accounting Software for Businesses, Businesstech, 2019.

[18] U.D. Dr Mahesh, "Role of accounting software in today scenario," International Journal of Research in Finance and Marketing, 6(6), 25-34, 2016.

[19] V.N.T. İ. Dalci, Benefits of Computerized Accounting Information Systems on the JIT Production Systems, Eastern Mediterranean University, 21-36.

[20] T. James, Types of Accounting Software, Chrone, 2019.

[21] What is a Spreadsheet?, My Accounting Course, 2020.

[22] K. Coloso, Best Accounting Software for Startups, Founders Guide, 2015.

[23] P. Griffiths, Accounting in the Cloud - Pros and Cons, Accru Chartered Accountants, 2020.

[24] What are the types of accounting software?, Shoebooks Team, 2012.

[25] A.A. Abu-Musa, "The Determinates Of Selecting Accounting Software: A Proposed Model," Review of Business Information Systems (RBIS), 9(3), 85-110, 2005, doi:10.19030/rbis.v9i3.4456.

[26] S.A. Tarboush, "Cloud Accounting As a New Business Model and Its Influence on Accounting Process," (2), 1-14, 2017.

[27] Ch. Krause, QuickBooks Online VS QuickBooks Desktop: Which Is Better?, Merchant Maverick, 2019.

[28] The way you work is changing. Our dedication to small business has not., QuickBooks, 2020.

[29] Accounting software that's free and powerful, Wave Accounting, 2020.

[30] Xero is online accounting software for your small business, Xero, 2020.

[31] Looking for accounting software?, Manager, 2020.

[32] E. Seppala, Best Accounting Software For Large Businesses, Merchant Maverick, 2020.

[33] Accounting software world, FinancialForce, 2020.

[34] J. Martinez, 5 Mistakes to Avoid When Choosing Accounting Software, PC, 2017.

[35] M. Pardo-Bunte, How Much Does Accounting Software Cost? 2020 Pricing Guide, BetterBuys, 2020.

[36] Global Accounting Software Market to be worth US $\$ 11,771.6 \mathrm{Mn}$ by 2026 : Transparency Market Research, Cision, 2018.

[37] Hardware and software IT services / Accounting software market, Fortune 869 
Business Insights, 2019.

[38] Accounting software market - growth, trends, and forecast (2020-2025), Mordor Intelligence, 2020.

[39] D. Epstein, What is Accounting Software? Analysis of Features, Types, Benefits and Pricing, FinancesOnline, 2020

[40] M. Gigante, 30+ Important Accounting Statistics You Need to Know in 2019, 2018.

[41] M.M. Thottoli, K. V. Thomas, R.A. Essia, "Adoption of Audit Software by Audit Firms: A Qualitative Study," Journal of Information and Computational Science, 9(9), 768-776, 2019.

[42] H. Rkein, "Saudi Journal of Business and Management Studies Impact of Automation on Accounting Profession and Employability: A Qualitative Assessment from Lebanon," Journal of Business and Management Studie, 4(4), 372-385, 2019, doi:10.21276/sjbms.2019.4.4.10. 